\title{
Metajęzykowe oblicze ironii
}

\section{The metalinguistic aspect of irony}

\begin{abstract}
The paper deals with the problem of relations between verbal irony and metalinguistic features of the natural language. It is shown that the irony in the vast majority of situations involves the reaction to a real or imagined speech, which proceeds from the fact that the human mind, the main target of irony, is explicated in a manner making it possible to be examined and evaluated precisely in speech. The target of the irony is man, his intellectual abilities, ethic and aesthetic choices, his views and beliefs, while his speech (word, statement, text, manner of speaking) turns out to be the direct pretext for ironic utterance.
\end{abstract}

Keywords: irony, metalinguistic expressions, Russian language, verbal, speech

Ekaterina Starodworskaja, Uniwersytet im. Adama Mickiewicza w Poznaniu, Poznań - Polska/ Irkucki Uniwersytet Państwowy, Irkuck - Rosja, starodvor@gmail.com, ORCID ID: https:// orcid.org/0000-0001-6323-2376

Celem niniejszego artykułu jest wstępne rozpoznanie jednego z zakresów funkcjonowania ironii, tzn. tych przypadków, które wiążą się z bezpośrednią metajęzykową reakcją na czyjąś wypowiedź, jej formę i treść, ukryte w niej wartości. Realizacja wspomnianego celu wymaga przypomnienia kluczowych zagadnień i pojęć, którymi będziemy operować podczas badania przykładów zawierających ironiczne wypowiedzi metajęzykowe - bezpośredni przedmiot przedstawionej analizy. Sam kluczowy termin użyty w tytule niniejszego referatu - ironia - już wymaga wyjaśnienia i deszyfracji, uściślenia tego, co rozumiemy przez to pojęcie. Nie jest to próżne pytanie, jak zobaczymy później, m.in. dlatego, iż liczni badacze, pracujący w różnorakich dziedzinach nauk humanistycznych, używają tego terminu w stosunku do, jak można się domyślać, różnych obiektów i mechanizmów. Jednakże obok terminu ironia występuje wiele innych, czasami nawiązujących do tych samych przykładów, wśród których wymienimy chociażby humor, komizm, sarkazm, antyfrazę, parodię, żart (listę tę można by kontynuować). 
Ironia jako zjawisko skomplikowane i wieloaspektowe, realizowane za pomocą rozmaitych środków (stricte językowych, przy czym ironia korzysta ze wszystkich podsystemów języka, szeroko pojętych komunikacyjnych, paralingwistycznych, przede wszystkim gestów i mimiki, strukturalnych i innych) w rozprawach humanistycznych (z dziedziny lingwistyki, literaturoznawstwa, filozofii, teorii sztuki etc.) może być pojmowana jako swoisty światopogląd, postawa filozoficzna, zasada artystyczna, sposób poznania i nauki, środek stylistyczny, akt komunikacyjny i strategia ponadtekstowa (Głowiński 6). Oczywiste jest, że tradycyjny opis ironii, spotykany jeszcze u autorów antycznych (,udawana skromność", przygana przez pochwałę), nie obejmuje całej różnorodności wypowiedzi ironicznych. Wśród tychże mieszczą się zarówno klasyczne przykłady, typu stwierdzenia: jaka ładna pogoda, wypowiedzianego w sytuacji, kiedy pogoda tak naprawdę jest brzydka (tutaj rzeczywiście ukryty sens jest zupełnie sprzeczny zarówno z jawnym znaczeniem przymiotnika oceniającego, jak i z szeroko pojętym kontekstem), jak i wypowiedzi bardziej skomplikowane, w których składzie może nie być żadnego elementu w jakikolwiek sposób związanego z ocenianiem:

[Panie A i B rozmawiają po tym, jak B najechała na krawężnik, wyjeżdżając z parkingu]

A: They just built that while you were in the store.

B: I know ${ }^{2}$ (Attardo 171).

Oczywiście nie jesteśmy w stanie zaproponować jedynego słusznego określenia ironii - realizacja tego celu wymagałaby publikacji kilkutomowej pracy zbiorowej. Skupmy się zatem na tych właściwościach ironii, które, jak się wydaje, decydują w większości przypadków o jej zastosowaniu i są bezpośrednio związane $\mathrm{z}$ jej aspektem metajęzykowym.

Salvatore Attardo, jeden z autorów ogólnej teorii humoru werbalnego (The General Theory of Verbal Humor), przywołuje powyższy przykład, by zaprezentować różnice pomiędzy ironią a humorem. Tych różnic, jak stwierdza Attardo, jest tak naprawdę niewiele, a jedna $\mathrm{z}$ nich to pełnienie przez ironię funkcji wartościowania, ewaluacji. Ocena, z którą mamy do czynienia za sprawą ironii, to niewątpliwie w większości przypadków ocena negatywna. Celem ironii, tym obiektem, który zostaje oceniony, jest przede wszystkim człowiek, tyle że nie sam w sobie, lecz jego cechy i właściwości - uogólniane i rozumiane jako pewien

${ }^{1}$ Przywołajmy przykład tego typu klasycznej definicji: „,троп [...], заключающийся в употреблении наименования (или целого высказывания) в смысле, прямо противоположном буквальному; перенос по контрасту, по полярности семантики” (Ènciklopediâ „Russkij âzyk” 1997).

2 A: Zbudowali to, kiedy byłaś w sklepie.

B: No wiem. 
światopogląd, zbiór typowych przekonań i zasad, wyznaczników pewnej kultury (nawet jeśli w konkretnej wypowiedzi formalnie chodzi np. o kopanie rowu czy budowę drogi):

Вот землекоп траншею роет, Вгрызаясь в грунт

За пядью пядь.

То пыль со лба стряхнет порою,

То потную откинет прядь.

$[\ldots]$

Вот он в земле почти по шею,

Вот он совсем пропал из глаз.

Растет и ширится траншея,

Такая нужная для нас.

А завтра утром

В час рассветный

Сюда он явится опять

И будет столь же беззаветно

Ее обратно засыпать.

$\mathrm{O}$, Русь, загадочная Русь,

Никак в тебе не разберусь.
By rzecz ująć z detalami temat tak zakończyć mogę:

budowaliśmy z kumplami

coś płaskiego, jakby drogę,

a że praca była ostra

i częściowo za darmochę,

droga wyszła dosyć prosta,

tylko wyboista trochę.

(W. Młynarski)

(И. Иртеньев)

W centrum uwagi znajduje się więc nie rów czy droga, zaś człowiek i jego działalność jako wyrażenie treści pewnej kultury, a nawet cywilizacji (w powyższym przypadku za pośrednictwem oceny typowych cech budownictwa socjalistycznego ocenia się system socjalistyczny jako taki).

Mechanizm ewaluacji polega m.in. na tym, że najpierw to, co się ocenia, powinno zostać zauważone, dostrzeżone, znaleźć się w polu widzenia odbiorcy. Jednak kolor skóry, kształt uszu czy długość palców, chociaż wszystkie te cechy dostrzec bardzo łatwo, same w sobie rzadko występują jako powód ironii. Dlaczego? Odpowiedź na to pytanie jest ściśle związana z podejściem do ironii jako do jednej z odmian implicytnej (ukrytej) agresji. Agresja jest właściwa człowiekowi w nie mniejszym stopniu niż np. szczurom czy gęsiom, jak to przekonywująco dowiódł jeszcze Konrad Lorenz w pracy Tak zwane zło. Jednak charakterystyczną cechą współczesnego społeczeństwa jest, jak zauważa Lorenz,

niemożność wyładowania agresywnych popędów w stopniu „przewidzianym” dla naszego gatunku. Zachowanie pokoju jest pierwszym obowiązkiem obywatelskim, a sąsiednia wroga wioska, która ongiś stanowiła obiekt zaspokajający wewnątrzgatunkową agresywność - znika w mglistej dali. W miarę coraz wyższego rozwoju cywilizacji wszystkie warunki sprzyjające właściwemu działaniu naszych naturalnych skłonności do społecznego zachowania się stają się coraz mniej korzystne, podczas gdy wymagania stawiane temu zachowaniu równocześnie 
wzrastają. „Bliźniego" każą nam traktować tak, jak gdyby był naszym najlepszym przyjacielem, pomimo że niekiedy nawet w ogóle go nie widzieliśmy. Co więcej, możemy rozumowo pojąć, że jesteśmy zobowiązani do miłowania także i naszych nieprzyjaciół, a to nigdy nie przyszłoby nam nawet na myśl na podstawie naszych naturalnych skłonności (Lorenz 292-293).

Eliminacja agresji czy nawet tego, co może zostać odebrane jako bezpodstawna agresja, staje się coraz bardziej radykalna (por. zjawisko poprawności politycznej $\left.{ }^{3}\right)$. Starając się, by nasze zachowanie było idealnie zgodne z normami społecznymi, rezygnujemy nie tylko z agresji fizycznej, lecz w wielu przypadkach również z jawnej agresji werbalnej (nawet o siódmej rano w zatłoczonym autobusie nie możemy powiedzieć komuś, kto nadepnął nam na stopę, że jest świnią czy łajdakiem ${ }^{4}$ ).

Jawna agresja jest niemożliwa (albo przynajmniej niepożądana), więc rozmówcy, dążąc do tego, by ich wypowiedzi były zgodne z Zasadą Uprzejmości, stosują agresję implicytną. Zasada Uprzejmości (Politeness Principle) została sformułowana przez brytyjskiego językoznawcę Geoffreya Leecha jako uzupełnienie słynnej Zasady Kooperacji Herberta Paula Grice'a ${ }^{5}$. Ta ostatnia opisuje ogólny mechanizm wydobywania przez odbiorcę ukrytych sensów wypowiedzi, sformułowanej przez nadawcę w konkretnej sytuacji komunikacyjnej, natomiast Zasada Uprzejmości wyjaśnia, w jakim celu nadawca w ogóle zadaje sobie trud formułowania wypowiedzi $\mathrm{w}$ ten (bardziej przecież skomplikowany), a nie inny sposób. Praktyczny sens przestrzegania Zasady Uprzejmości został ujęty przez Leecha w następujący sposób: „unless you are polite to your neighbour, the channel of communication between you will break down, and you will no longer be able to borrow his mower" (Leech 82) ${ }^{6}$.

Ironię Leech pojmuje jako drugorzędną zasadę, która eksploatuje Zasadę Uprzejmości i opisuje jej mechanizm następująco: „If you must cause offence, at least do so in a way which doesn't overtly conflict with the PP, but allows the

${ }^{3}$ Zwróćmy uwagę chociażby na stopniowo ewoluujący zakaz używania w przestrzeni publicznej - przede wszystkim w Stanach Zjednoczonych - tzw. słowa na literę N ( $N$-word), najpierw jako określenia nacechowanego negatywnie i pełniącego funkcję pejoratywną, aktualnie - nawet w cytatach czy refleksji na temat używania tegoż słowa.

${ }^{4}$ Oczywiście powiedzieć jednak możemy, ale w tym przypadku będziemy musieli pogodzić się z konsekwencjami, które w mniejszym czy większym stopniu polegałyby na tymczasowym czy stałym wykluczeniu ze wspólnoty.

${ }^{5}$ Przypomnijmy, jak ta zasada działa według Grice’a w przypadku ironii: „Dla A i jego słuchaczy jest rzeczą zupełnie oczywistą, że A nie wierzy w to, co powiedział; słuchacze wiedzą przy tym, iż A wie, że jest to dla nich oczywiste. Jeśli więc wypowiedź A miała w ogóle o czymś informować, to A chciał zapewne wygłosić inny sąd niż ten, który wygłosił. Musi to być sąd w jakiś wyraźny sposób powiązany z wygłoszonym; najoczywistszym związkiem jest tu sprzeczność” (Grice 107).

${ }^{6}$ „Jeśli jesteś nieuprzejmy w stosunku do swojego sąsiada, kontakt między wami urwie się i nie będziesz mógł dłużej pożyczać od niego kosiarki”. 
hearer to arrive at the offensive point of your remark indirectly, by way of implicature" (Leech 82) ${ }^{7}$. Poniższy przykład może posłużyć jako wyrazista ilustracja ukrycia obraźliwego sensu wypowiedzi za pomocą ironii, ze względów przeważnie pragmatycznych:

\begin{abstract}
Читка „Джаз-комедии” закончилась. Серьезные, искушенные в искусстве люди обрели вновь свою серьезность и искушенность. - Вещь блестяще талантлива, - сказали они, - но социального хребта в ней нет. После столь глубокомысленного вывода мои коллеги стали резать сценарий под корень, как режут сорную траву. Я не буду приводить имен и цитат. Из имен можно составить не одну славную страницу истории советского кинематографа (Aleksandrov 1976) .
\end{abstract}

Skoro już nadawca (w tym przypadku autor wspomnień, radziecki reżyser, który, co oczywiste, tak naprawdę nie uważa wniosku komisji za głęboki i przemyślany, ale nie przekazuje tej informacji wprost; zwróćmy uwagę także i na szerszy kontekst: za ukryciem negatywnej oceny idzie ukrycie imion i nazwisk tych, którzy, zdaniem autora, zachowali się co najmniej nieuczciwie) podejmuje starania, by zakamuflować negatywną ocenę, byłoby szkoda, żeby ten wysiłek poszedł na marne, czyli na opis tego, na co człowiek nie ma wpływu, co od niego nie zależy (jak wspomniany kształt uszu czy długość palców). Wypowiedź celująca $\mathrm{w}$ wygląd zewnętrzny, nawet niejawnie negatywna, i tak zostanie odebrana jako nieuprzejma/niestosowna lub nawet absurdalna.

Tym sposobem dochodzimy do wniosku, iż oceniane cechy powinny mieć wartość semiotyczną, ponieważ ironiczny komentarz jest związany z ich wewnętrzną treścią (albo z tym, co mówca uważa za ich wewnętrzną treść). Nie ma więc nic dziwnego, że ironia $\mathrm{w}$ wielu sytuacjach wiąże się z reakcją na pewną realną bądź wymyśloną wypowiedź, gdyż ludzka świadomość i - szerzej światopogląd, główny cel ironii, stają się widoczne przede wszystkim w języku, mowie, akcie komunikacji. Podsumowując, celem ironii jest człowiek, jego zdolności intelektualne, wybory estetyczne i etyczne, przyswojone przez niego poglądy, jego kulturowa czy polityczna tożsamość, a bezpośredni pretekst, powód do ironicznej wypowiedzi to szeroko pojęta mowa (w konkretnych przypadkach jawiąca się jako słowo, zdanie, wypowiedź, tekst, sposób mówienia etc.), w ktorej zostały zawarte. Trzeba zauważyć, że najważniejszą rolę odgrywa tutaj postać interpretatora, ironisty właśnie, który jest $\mathrm{w}$ stanie dostrzec $\mathrm{w}$ wypowiedzi treść podlegającą ocenie i odnieść się do niej:

${ }^{7}$ „Jeśli już musisz kogoś obrazić, rób to w taki sposób, który nie będzie jawnie sprzeczny z Zasadą Uprzejmości, ale umożliwi odbiorcy pośrednie wydobycie obraźliwego sensu twojej wypowiedzi - przez wyciągnięcie implikatury".

${ }^{8}$ Tu i dalej przykłady z Narodowego Korpusu Języka Rosyjskiego. 
- Вчера бежала я за вами, бежала, все ноги стерла, - рассказала баба Лиза (рыночная торговка). - Прямо сердце захолонуло. А вас и след простыл.

- Как вы на таком ветру целый день? - спросила я.

- Такая жизень наша страшная, - с удовольствием сказала баба Лиза.

Nie jest ważne - przynajmniej dla stwierdzenia faktu obecności ironii w powyższym przykładzie - czy narrator (rosyjska pisarka Tatiana Tołstaja) faktycznie dostrzegł intonację zadowolenia w wypowiedzi interlokutorki, czy ta charakterystyka została przez pisarkę narzucona; najważniejsze, że wypowiedź jest traktowana jako wyraz pewnego stanu psychicznego, być może nawet światopoglądu, do którego narrator nastawiony jest co najmniej sceptycznie.

Kolejnym dowodem na to, że ironia to bardzo często reakcja na czyjąś wypowiedź (lub to, co zostaje odebrane jako wypowiedź, słowo, akt komunikacyjny, sposób wypowiadania się etc.), są współczesne teorie ironicznego dekonstruowania sensu, m.in.:

- teoria przywołania (The Echoic Mention Theory) Dana Sperbera i Deirdre Wilson (1992), polegająca na tym, że mówca odcina się od wygłoszonego przez siebie sądu (bo w rzeczywistości ten sąd należy/może należeć do kogoś innego), co wiąże się z pragmatycznym efektem wyśmiewania i pogardy wobec tego innego, a raczej jego sądu;

- teoria udawania (The Pretence Theory) Raymonda Gibbsa i Herberta Colstona (Clark, Herrig): ironista udaje osobę, która mogłaby wypowiedzieć się w taki właśnie sposób serio i jednocześnie uwypukla kontrast pomiędzy sobą i wspomnianą osobą, swoimi a jej poglądami; można tutaj przywołać również koncepcję obcego słowa Michaiła Bachtina (Vološinov).

Jest jasne, że autorka powieści o represjach stalinowskich Lidia Czukowska nie solidaryzuje się z wypowiedzią Andrieja Żdanowa w sprawie czasopism „Zvezda” i „Leningrad” i nie pochwala jej, zaś używa utartych zwrotów z radzieckich gazet, udaje słuszną ideologiczną postawę, by „wysadzić” te zwroty od środka i wprowadzić skrajnie negatywną ocenę tej postawy: „Поэзию Axматовой Жданов попросту, по-нашему, по-рабочему, с большевистской прямотой определил так: «хлам»”. Porównajmy rzeczywiste cytaty z radzieckich gazet:

Но мы должны с полной революционной прямотой сказать, что работа профессиональных и общественных организаций [...] в области вооружения техникой рабочих, колхозников, хозяйственников не находится еще в соответствии с задачами третьего, решающего года пятилетки („Izvestiâ”, 9.03.1931).

Успехи русских в космосе стали для нас привычными, - заявил корреспонденту ТАСС механик одного из тунисских предприятий. - Поэтому я затрудняюсь дать оценку этому событию. Одним словом, по-нашему, по-рабочему, это здорово! („Večernââ Moskva”, 16.06.1963). 
- teoria pośredniej negacji (The Indirect Negation Theory) Rachel Giory (Giora, Fein, Schwartz) skupia się na tym, iż ironia polega na ukrytym zaprzeczeniu tego, co zostało jawnie wypowiedziane.

Wszystkie te koncepcje mają więc ze sobą coś wspólnego: wynika z nich, że ironia jest zawsze i bezpośrednio związana z pewną lingwistyczną substancją, z językowym „opakowaniem” pewnej myśli, poglądu, sądu.

Właśnie to „opakowanie”, będąc, po pierwsze, łatwo zauważalne, a po drugie, zawierając w sobie treść wartą oceniania, komentowania i dyskusji, bardzo często występuje jako powód do ironii, a ta ironia zostaje zawarta w komentarzu do wypowiedzi. W związku z tym niezwykle perspektywicznym kierunkiem badań ironii werbalnej jest analiza jednego z jej najbardziej efektywnych lingwistycznych narzędzi, mianowicie tzw. wyrazów metajęzykowych, pełniących funkcję sygnału ironii, a jednocześnie występujących jako semantyczny współczynnik tego zjawiska. Wszystkie przykłady użyte w artykule (za wyjątkiem dwóch pierwszych cytatów z Irteniewa i Młynarskiego), zarówno te przywołane wyżej, jak i kolejne, są zbudowane według określonej struktury, której podstawowymi składnikami są czyjaś wypowiedź, najczęściej bohatera, i autorski komentarz do niej, zawierający wyraz metajęzykowy.

Termin metajęzykowy został tutaj użyty zgodnie z definicją Romana Jakobsona, który, wymieniając główne funkcje aktu mowy, pisze o funkcji metajęzykowej w następujący sposób:

W nowoczesnej logice zostało dokonane rozróżnienie między dwiema płaszczyznami języka: ,językiem przedmiotowym”, mówiącym o przedmiotach, i „metajęzykiem”, mówiącym o samym języku [...]. Lecz metajęzyk jest nie tylko koniecznym instrumentem naukowym używanym przez logików i lingwistów. Gra on również ważną rolę w naszej mowie codziennej. Podobnie jak Jourdain Molièr'a, który nie wiedział, że mówi prozą, używamy metajęzyka, nie zdając sobie sprawy z charakteru metajęzykowego naszej działalności. Ilekroć nadawca lub odbiorca chcą sprawdzić, czy posługują się jednakowym kodem, mowa zostaje sprowadzona do kodu: przybiera ona funkcję metajęzykową (Jakobson 438).

Podstawowym składnikiem dekonstrukcji ironicznej, na co wskazują chyba wszyscy ironiolodzy, jest sprzeczność pomiędzy jawnie przedstawioną, konwencjonalną treścią a szeroko rozumianym kontekstem oraz ukrytym sensem, który zostaje wyciągnięty przez odbiorcę właśnie na podstawie negacji dosłownego znaczenia.

Analiza wyrazów metajęzykowych pod kątem ironii wiąże się z określeniem rodzaju sprzeczności pomiędzy wypowiedzią nadaną bezpośrednio przez autora tekstu literackego, przede wszystkim prozatorskiego lub non-fiction (lub bohatera tegoż tekstu) a wyrazem metajęzykowym użytym jako komentarz do tej właśnie wypowiedzi. 
Przywołajmy jeszcze kilka przykładów wspomnianej sprzeczności, pokażmy uniwersalność opisywanego w artykule mechanizmu ironii, jak również ustalmy, na czym polega ta sprzeczność:

- У нас опять что-нибудь взорвалось? - светски осведомился я. - Пока нет, - с оптимизмом ответил Салас (http://samlib.ru/i/izmajlowa_k_a//good.shtml) ${ }^{9}$.

Wyraz metajęzykowy с оптимизмом ответил wspiera tutaj ogólnie ironiczną strategię tekstu, a odrębne komponenty, zawarte w semantycznej strukturze rzeczownika оптимизм są sprzeczne z jawnie przedstawioną informacją o realnej możliwości wybuchu ['бодрое и жизнерадостное мироощущение, исполненное веры в будущее; склонность во всем видеть хорошие, светлые стороны' (Evgen'eva)].

Один робкий турист страшился близко подходить к обрыву. - А что мне делать, - обратился он к гиду, - если я упаду? - В этом случае, сэр, - с энтузиазмом ответил гид, - не забудьте посмотреть направо. Вид там просто потрясающий! (https://self.wikireading. $\mathrm{ru} / 11681)$

Zauważmy, że $c$ оптимизмом to raczej charakterystyka treści wypowiedzi (оптимистичное высказывание zasadniczo nie wymaga widocznego ożywienia nadawcy), natomiast $c$ энтузиазмом raczej komentuje formę. W tym przypadku celem miękkiej ironii jest szalenie zaangażowany przewodnik, który nawet w sytuacji śmiertelnego niebezpieczeństwa umie odnaleźć powód do zachwytu. Analiza tego przykładu umożliwi nam także demonstrację tego, czym ironia różni się od językowego żartu, który tutaj został zrealizowany jako pointa dowcipu. Dowcip zostałby dowcipem nawet w przypadku braku drugiego wyrazu metajęzykowego: żart, jak widzimy, nie wymaga sprzeczności jawnego i ukrytego sensu, tylko nieoczekiwanego wniosku, szokującej pointy.

Sprzeczność pomiędzy treścią, formą czy szeroko rozumianym kontekstem wypowiedzi a komentarzem metajęzykowym jest, jak się wydaje, uniwersalnym mechanizmem ironicznego przekazu (nie tylko w języku rosyjskim):

The best bit of the park, I was told enthusiastically by our fixer prior to arrival, was the grand, looped roller coaster built under the guidance and inspiration of Kim Il-sung himself. Without his wisdom, the ideologue explained, Korea would never have become the world class nationstate it currently is... (https://www.vice.com/en_au/article/kwn85e/north-korea-fun-fair-mangyongdae-hoban-death)

Tutaj wyraz metajęzykowy to tell enthusiastically jest odbierany ironicznie głównie na podstawie sprzeczności pomiędzy entuzjazmem przewodnika a wiedzą narratora (i, oczywiście, odbiorcy tekstu) o stanie rzeczy, typowym dla totalitarnego

9 Ten przykład i dalsze są wynikami wyszukiwania w Google. 
państwa. Entuzjazm pośrednika zostaje więc oceniony jako sztuczny i na ogół absurdalny (co jest podkreślone przez wspomnienie osobistego udziału głowy państwa w opracowaniu projektu kolejki w wesołym miasteczku).

„Ten model ma całkiem nowy kształt perforacji siateczki tnącej” - powiedzial entuzjastycznie Brand manager CEEMEA marki Braun, dumnie potrząsając depilatorem - „Super, prawda?” (http://web.adwertajzing.pl/kampania.php?id=3)

W tym przypadku przyczyna entuzjastycznego podejścia managera (mianowicie charakterystyka techniczna produktu) nie wydaje się autorowi komentarza uzasadniona, entuzjazm jest oceniany jako sztuczny i nieszczery, a celem ironii, jak się wydaje, jest nie tyle wspomniany manager sam w sobie, lecz rozpowszechniony i nieprzekonywujący styl promocji towaru. Raz jeszcze chcę podkreślić reprezentatywność ironicznego nacechowania wyrazów metajęzykowych jako reakcji na komentowaną wypowiedź, która nie jest oceniana jako taka, lecz jako wyraz treści kulturowych i światopoglądowych, mających wartość semiotyczną.

Związek pomiędzy wypowiedzią ironiczną, która jest tak naprawdę cytatem, i jakąś inną wypowiedzią (bardzo często identyczną formalnie, merytorycznie, ale nie pragmatycznie) nie zawsze przedstawiony explicite, zauważony przez badaczy, m.in. Michaiła Bachtina i Rolanda Barthesa, nie został na razie szczegółowo przedstawiony w literaturze lingwistycznej. W artykule skupiliśmy się na tych przypadkach, w których cytowana, komentowana wypowiedź jest przedstawiona w sposób jawny i sprzeczność się uzewnętrznia (co w żadnym wypadku nie oznacza, że semantyka komentarza nie zawiera wewnętrznej sprzeczności). Przykłady o takiej strukturze jasno przedstawiają sprzeczne składniki ironicznej wypowiedzi, a więc pozwalają uściślić rodzaj i stopień sprzeczności.

Podkreślmy raz jeszcze, na czym polegają relacje pomiędzy ironią a funkcją metajęzykową języka naturalnego:

- ironia jest „opakowaniem” oceny (zwykle negatywnej);

- ocenia się człowieka;

- przedmiotem oceny nie jest jednak człowiek jako taki, lecz przypisane mu przez ironistę wartości i poglądy - to, co człowiek wybiera z własnej woli, za co ponosi odpowiedzialność;

- wartości i poglądy owe stają się widoczne przede wszystkim w wypowiedziach (albo tym, co traktuje się jako wypowiedź);

- koniec końców, ocenia się więc wypowiedź, a przez nią - jej autora, jego poglądy;

- ten mechanizm najbardziej przezroczyście wygląda właśnie w przypadku użycia przez autora wyrazów metajęzykowych komentujących treść wypowiedzi bohatera, a więc, jak się wydaje, takie użycia zasługują na bardziej rozbudowaną i szczegółową analizę. 


\section{Bibliografia}

Aleksandrov, Grigorij. Èpoha i kino. Moskva, Politizdat, 1976.

Attardo, Salvatore. „Humor and Irony in Interaction: From Mode Adoption to Failure of Detection”. Say not to Say: New Perspectives on Miscommunication. Red. Luigi Anolli, Rita Ciceri, Giuseppe Riva. Amsterdam-Washington, IOS Press, 2002, s. 166-185.

Clark, Herbert, Richard J. Gerrig. „On the Pretense Theory of Irony”. Journal of Experimental Psychology, nr 113, 1984, s. 121-126.

Ènciklopediâ „Russkij âzyk”. Moskva, Naučnoe izdtel'stvo BRE, 1997.

Evgen'eva, Anastasiâ P., red. Slovar' russkogo âzyka: w 4-ch t. Moskva, Poligrafresursy, 1999.

Gibbs, Raymond. „On the Psycholinguistics of Sarcasm”. Journal of Experimental Psychology, nr 105, 1986, s. 3-15.

Giora, Rachel, Ofer Fein, Tamir Schwartz. „Irony: Graded Salience and Indirect Negation”. Metaphor and Symbol, nr 13, 1998, s. 83-101.

Głowiński, Michał. „Ironia jako akt komunikacyjny”. Ironia. Red. Michał Głowiński. Gdańsk, Słowo/obraz terytoria, 2002, s. 5-16.

Grice, Paul. „Logika a konwersacja”. Język w świetle nauki. Red. Barbara Stanosz. Warszawa, Czytelnik, 1980, s. 91-114.

Jakobson, Roman. „Poetyka w świetle językoznawstwa”. Pamiętnik Literacki, nr 2, 1960, s. 431473.

Leech, Geoffrey N. Principles of Pragmatics. London, Longman, 1983.

Lorenz, Konrad. Tak zwane zło. Przeł. Anna D. Tauszyńska. Warszawa, PIW, 1972.

Vološinov, Valentin N. Marksizm i filosofiâ âzyka. Leningrad, Priboj, 1929.

Wilson, Deirdre, Dan Sperber. „On Verbal Irony”. Lingua, nr 87, 1992, s. 53-76. 